\title{
Erythropoietin Administration for Anemia Due to Chronic Kidney Disease - Subcutaneous OR Intravenous, What Do We Know So Far?
}

\author{
Muhammad Hasan Shahab 1, 2 , Shahzeen Saifullah Khan 3, 2 \\ 1. Internal Medicine, Memon Medical Institute Hospital, Karachi, PAK 2. Paediatrics, Dr. Ruth K.M. Pfau Civil Hospital \\ Karachi / Dow Medical College, Karachi, PAK 3. Accident and Emergency, Memon Medical Institute Hospital, Karachi, \\ PAK
}

Corresponding author: Muhammad Hasan Shahab, hasan.s_1993@hotmail.com

\begin{abstract}
The prevalence of anemia in chronic kidney disease (CKD) patients is almost twice that of the normal population and its severity increases exponentially as the disease worsens, dramatically affecting the quality of an individual's life. The advent of erythropoiesis stimulating agents (ESA) in the 1980s saw a

revolutionary change in the treatment of anemia in CKD patients, drastically improving quality of life (QoL), overall health and reducing the need for blood transfusions. Numerous ESAs have been developed ever since and are in current use, with the primary routes of administration being intravenous (IV) and subcutaneous (SC) injections. Their use, however, has stirred significant controversy over the last two decades. Additionally, despite numerous studies and trials, the latest international recommendations for their use do not provide clear cut guidance with well-grounded evidence on the recommended route of administration for different sets of patients. Instead, this decision has mainly been left up to the physician's discretion, whilst keeping certain key factors in mind. This review shall summarize, discuss and compare the findings of previous studies on various factors governing the two aforementioned routes of administration and identify areas that need further exploration.
\end{abstract}

Categories: Internal Medicine, Nephrology

Keywords: chronic kidney disease, esrd, subcutaneous, intravenous, erythropoietin, dialysis, cost, efficacy, frequency, anemia

Received 08/26/2020

Review began 09/01/2020 Review ended 09/02/2020 Published 09/10/2020

() Copyright 2020

Shahab et al. This is an open access article distributed under the terms of the Creative Commons Attribution License CC-BY 4.0., which permits unrestricted use, distribution, and reproduction in any medium, provided the original author and source are credited.

\section{Introduction And Background}

Anemia, defined as serum haemoglobin $(\mathrm{Hb})$ levels $\leqslant 12 \mathrm{gm} / \mathrm{dL}$ in women and $\leqslant 13 \mathrm{gm} / \mathrm{dL}$ in men, is a common complication of chronic kidney disease (CKD), being prevalent twice as much in the affected adult population (15.4\%) as opposed to the general population (7.4\%). The prevalence of anemia tends to be correlated with the severity of underlying kidney disease, prevailing in $8.1 \%$ of patients with stage 1 CKD to $53.4 \%$ in stage 5 CKD [1]. It is frequently associated with a poorer quality of life (QoL) that deteriorates further as the disease progresses, and commonly results in cognitive impairment, reduced exercise capacity, worsening of cardiac function, increased cardiovascular morbidity and ultimately contributes to an increased overall mortality rate $[1,2]$.

Poor kidney function and accumulation of uremic toxins is a known cause of anemia in CKD patients in addition to reduced erythropoietin (EPO) production due to loss of functioning renal parenchyma, hyporesponsiveness to EPO, iron deficiency, chronic inflammation, and shortened red blood cell survival [13].

If left untreated, it has a significant detrimental impact on the patient's QoL, their overall health and healthcare costs. A study in pre-dialysis CKD patients found a significant increase $(p<0.0001)$ in monthly treatment costs between CKD patients who had untreated anemia against those without anemia. In a similar study involving patients with end-stage renal disease (ESRD), who were undergoing dialysis, medical costs were found to be $8.9 \%$ higher for every month of treatment when Serum Hb was less than $11 \mathrm{gm} / \mathrm{dL}$ [2].

While the treatment of anemia in CKD involves managing multiple causative factors as highlighted above, the most significant factor is the deficiency of EPO. As a result, the use of erythropoiesis stimulating agents (ESAs) since 1989 has significantly improved the management of anemia [4]. The need for blood transfusions in CKD patients has gone down significantly, whilst improving QoL and exercise capacity $[5,6]$. A study conducted in the United States in 2005 indicated almost $99 \%$ of in-center haemodialysis (HD) patients receiving ESA. The magnitude of the revolutionary change brought by these agents can also be estimated from the fact that in 2004, EPO therapy totaled $\$ 1.8$ billion - the single largest Medicare drug expenditure in the United States $[4,7]$.

The 2012 Kidney Disease Improving Global Outcomes (KDIGO) guidelines regarding anemia in CKD present 
evidence and recommendations of varying strength. With regards to ESA therapy in adult CKD patients, they strongly recommend against intentionally increasing $\mathrm{Hb}>13.0 \mathrm{gm} / \mathrm{dl}$, backed by high quality evidence. They suggest that ESA therapy should be initiated in ESRD patients when $\mathrm{Hb}$ is between 9-10.0 gm/dl with an aim to keep it above $10 \mathrm{gm} / \mathrm{dl}$ but not above $11.5 \mathrm{gm} / \mathrm{dl}$, backed by low to moderate quality evidence [8]. In patients with non-dialysis dependent, advanced CKD with $\mathrm{Hb}<10.0 \mathrm{gm} / \mathrm{dl}$, they suggest that the decision to treat using ESAs should be weighed against various other factors but this is supported by low quality evidence. These guidelines however, exhibit low to very low quality evidence when it comes to recommendations about the type of ESA, dosing frequency, and their route of administration, the last of which is the main focus of this review [8].

Since their inception, ESAs have undergone significant development and innovation, in line with associated healthcare costs, pharmacokinetics, drug efficacy, side effect profiles and dosing frequency as well as the route of administration. The ones commonly used include the first generation erythropoietin-alfa and beta and the second generation agent Darbepoetin [4]. Their use, however, has come under serious scrutiny over the last two decades owing to certain studies that showed an increase in overall mortality and adverse cardiovascular as well as cerebrovascular events [9].

Target $\mathrm{Hb}$ levels secondary to ESA therapy remain a matter of controversy worldwide, with higher Hb targets (>11.0 gm/dl) being tied to an increased risk of adverse events and no significant improvement in QoL against that of partially corrected anemia, i.e., $\mathrm{Hb}(9.5-11.0) \mathrm{gm} / \mathrm{dl}[8,10]$. One rare outcome that gained significant attention was that of ESA-induced pure red cell aplasia (PRCA) between 1998 and 2004, mainly associated with the subcutaneous (SC) route of administration, and the exact cause of which is thought to be the production of anti-EPO antibodies. However, this was found to be associated with one specific product of epoetin-alfa "Eprex/Erypo" in Europe and was not associated at the same scale with other subcutaneously administered epoetin products. This was appropriately dealt with by the formulation of ESAs with a new structure $[11,12]$.

\section{Review}

\section{Method}

For this review, we performed a literature search on the PubMed database (1988 - Present date) using combinations of multiple keywords and Medical Subject Heading (MeSH) terms - anemia, ESRD, erythropoietin, dialysis, chronic kidney disease, patient satisfaction, etc. The study types that were reviewed included review articles, meta-analyses, systematic reviews, multicenter studies, randomized clinical trials, excerpts from various journals and documents, and clinical trials. To meet the criteria for inclusion, articles also needed to involve human subjects only and be published in English. Case reports, editorials, commentaries, opinions and animal studies were not included in this review. The most important point for inclusion was individual article relevance to the scope of this review. However, this was carried out manually after screening articles on the basis of their titles and abstracts.

\section{Results}

Using the aforementioned searching strategy, we found a total of 41,271 articles, of which 35,419 were found to be duplicated (see Table 1). A total of 5,852 articles were therefore found after the initial search. 


\section{Cureus}

\begin{tabular}{|c|c|c|c|}
\hline Search number & \multicolumn{2}{|l|}{ Query } & Results \\
\hline 1 & \multicolumn{2}{|c|}{ Erythropoietin AND Quality Of Life } & 1,302 \\
\hline 2 & \multicolumn{2}{|l|}{ Erythropoletin AND ESRD } & 3,519 \\
\hline 3 & \multicolumn{2}{|c|}{ Erytnropoletin ANUD Sarety AND ESRD } & 229 \\
\hline 4 & \multicolumn{2}{|c|}{ Erythropoietin AND Pure Cell Red Aplasia } & 272 \\
\hline 5 & \multicolumn{2}{|c|}{ ESRD AND Pure Cell Aplasia } & 86 \\
\hline 6 & \multicolumn{2}{|c|}{ Erythropoietin AND Cost AND Subcutaneous } & 109 \\
\hline 7 & \multicolumn{2}{|c|}{ Anemia AND Chronic Kidney Disease } & 7,353 \\
\hline 8 & \multicolumn{2}{|l|}{ Anemia AND ESRD } & 5,322 \\
\hline 9 & \multicolumn{2}{|l|}{ Erythropoietin AND Anemia } & 8,941 \\
\hline 10 & \multicolumn{2}{|l|}{ Erytnropoietin AIND Dialysis } & 4,158 \\
\hline 11 & \multicolumn{2}{|c|}{ Erythropoietin AND Haemodialysis } & 4,162 \\
\hline 12 & \multicolumn{2}{|c|}{ Erythropoietin AND Health Cost } & 361 \\
\hline 13 & \multicolumn{2}{|c|}{ Erythropoietin AND Treatment Adherence And Compliance } & 140 \\
\hline 14 & \multicolumn{2}{|c|}{ Erythropoietin AND Patient Satisfaction AND Quality Of Life } & 20 \\
\hline 15 & \multicolumn{2}{|c|}{ Erythropoietin AND Chronic KIdney Disease AND Dialysis } & 2,829 \\
\hline 16 & \multicolumn{2}{|c|}{ Erythropoietin AND ESRD AND Dialysis } & 2,468 \\
\hline TOTAL SEARCH & & 41,271 & \\
\hline DUPLICATED AR & & 35,419 & \\
\hline IOIAL ARIICLES & LCUDING DUPLICAIES) & 5852 & \\
\hline
\end{tabular}

TABLE 1: Results of the initial literature search, carried out on 15th August 2020, on the PubMed Database using combinations of different MeSH terms and regular keywords

ESRD: End-stage renal disease; MeSH: Medical Subject Heading

These were then further filtered for articles that were pertinent to the confines of this review by another search carried out using "EndNote X9 ${ }^{\circledR}$ ”, a citation management software, by utilizing a comprehensive list of relevant MeSH terms and regular keywords (see Table 2). Ultimately we were able to narrow down our search to 160 articles that we felt were pertinent to the scope of this review. Out of 160 articles, 38 full-text publications were then chosen for discussion in this literature review, with the merit of selection being individual article relevance and comprehensiveness. 


\section{Cureus}

\section{MeSH Terms}

Erythropoietin

Erythropoietin / adverse effects

Erythropoietin / pharmacokinetics

Kidney failure, chronic

Chronic kidney disease

ESRD

Renal dialysis

Health cost

Epoetin alfa

Erythropoietin / administration \& dosage

Kidney failure, chronic / complications

Injections, intravenous

Injections, subcutaneous

Quality of life

Patient compliance

Treatment adherence and compliance

Patient satisfaction

Patient preference
Regular Keywords

Chronic renal disease

Costs

Patient preference

Anemia

ESRD

Erythropoietin

Convenience

Haemodialysis

Chronic kidney disease

Injection

Preference

Subcutaneous

Intravenous

Haemodialysis

Administration route

Pain

Efficacy

Safety and tolerance

TABLE 2: A comprehensive list of various MeSH terms and regular keywords used for filtering relevant articles after the initial search, using "EndNote X9 ®"

ESRD: End-stage renal disease; MeSH: Medical Subject Heading

\section{Discussion}

The major factors that govern the route of ESA administration include the patient's stage of CKD, efficacy considerations, the type of ESA used, dosing frequency, convenience, healthcare costs, and drug safety and tolerability $[8,12]$. This literature review aims to discuss the existing, relevant literature for these factors with respect to the route of ESA administration and to define areas that need further exploration.

Dosing Frequency

Numerous studies and trials have documented evidence strongly suggestive of the advantages that the SC route of erythropoietin administration has, in terms of requiring a lower dose and frequency of administration, over the IV route (see Table 3). 


\section{Cureus}

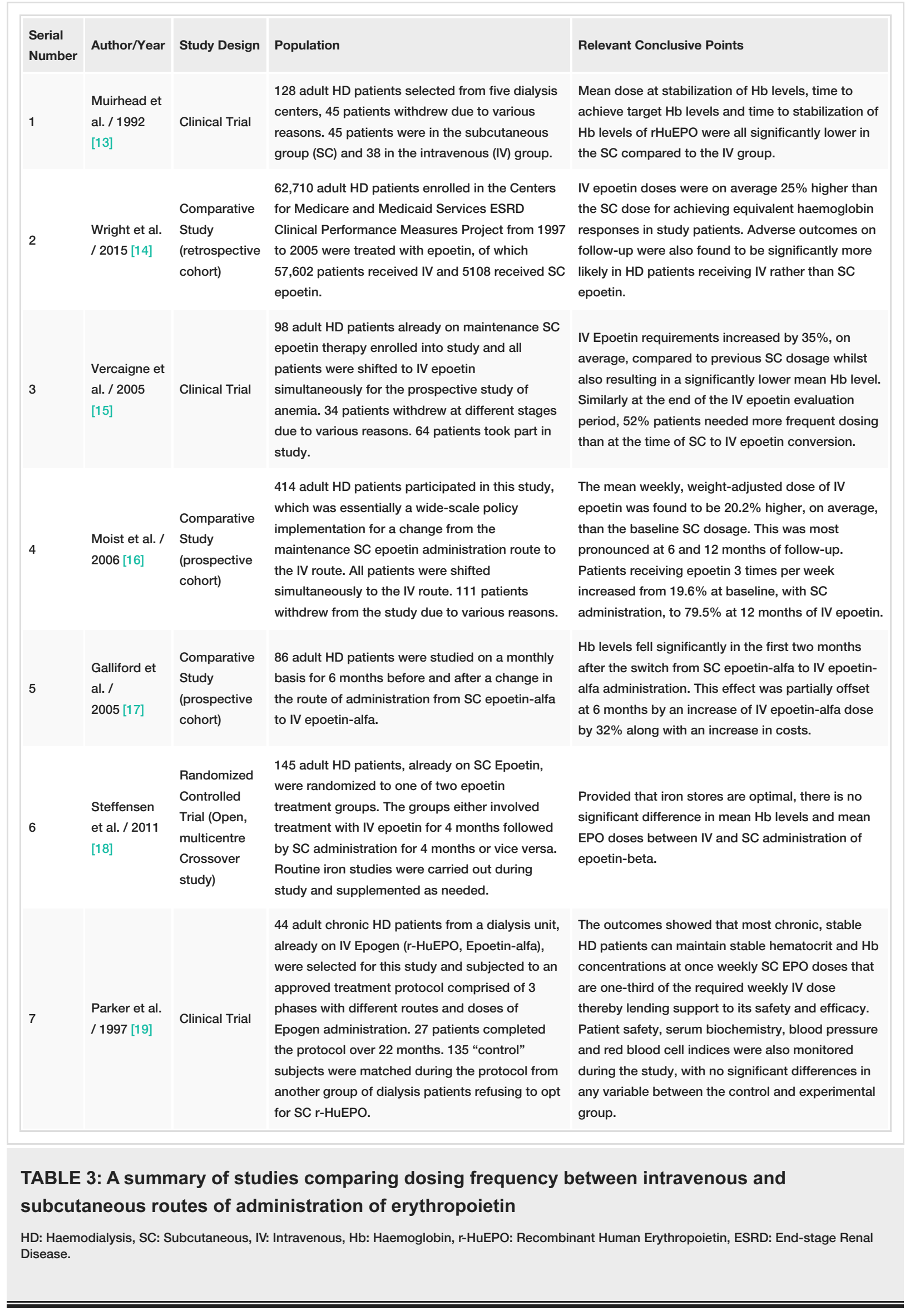


As with any other drug, recombinant Human EPO (r-HuEPO) or epoetin carries with it a certain set of side effects. While both IV and SC share some of these adverse effects, the extent and frequency differ between the two (see Table 4). Common to both routes include injection site pain sensation, the development of hypertension, arteriovenous fistulae thrombosis, an increased overall risk of thrombotic and cardiovascular as well as cerebrovascular events, hyperkalemia, depletion of iron stores, flu-like symptoms, a prolonged duration of dialysis and rarely, PRCA and seizures $[9,11,12,20]$.

\begin{tabular}{|c|c|c|c|c|}
\hline $\begin{array}{l}\text { Serial } \\
\text { Number }\end{array}$ & Author/Year & Study Design & Population & Relevant Conclusive Points \\
\hline 1 & $\begin{array}{l}\text { Lee et al. / } \\
2009 \text { [21] }\end{array}$ & $\begin{array}{l}\text { Randomized } \\
\text { Controlled } \\
\text { Trial }\end{array}$ & $\begin{array}{l}78 \text { adult HD patients were randomly } \\
\text { assigned to either receive IV or SC epoetin. } \\
\text { The time to Vascular access failure was } \\
\text { analysed. Seven patients were withdrawn } \\
\text { from evaluation due to various reasons. }\end{array}$ & $\begin{array}{l}\text { Patients in the SC therapy group exhibited a } \\
\text { significantly higher rate ( } 12.0 \% / \text { patient year) of access } \\
\text { failure as compared to the IV epoetin group } \\
\text { ( } 4.7 \% \text { /patient year). The study was limited, however, by } \\
\text { a small sample size and asymmetry between the two } \\
\text { groups. }\end{array}$ \\
\hline 2 & $\begin{array}{l}\text { Klinkmann et } \\
\text { al. / } 1992 \text { [22] }\end{array}$ & $\begin{array}{l}\text { Clinical Trial } \\
\text { (Prospective, } \\
\text { Multi-center } \\
\text { study) }\end{array}$ & $\begin{array}{l}362 \text { adult HD patients from } 16 \text { European } \\
\text { dialysis centers entered the study with half } \\
\text { of the patients receiving r-HuEPO during } \\
\text { the first year (first phase) of the trial and } \\
\text { then serving as the control group during the } \\
\text { second year (second phase) and the other } \\
\text { half followed the opposite treatment plan. } \\
\text { These patients were monitored for the drug } \\
\text { safety of SC administered EPO. A total of } \\
73 \text { patients dropped out from the study. }\end{array}$ & $\begin{array}{l}\text { Adverse events (AE) were recorded in the two groups, } \\
\text { as serious and non-serious. AE were higher in the SC } \\
\text { therapy group ( } 55.9 \% \text { ) compared to the control group } \\
\text { ( } 44.1 \% \text { ), with serious AE being slightly higher in the } \\
\text { therapy group. Statistically however, there was no } \\
\text { significant difference between the two groups in terms } \\
\text { of serious AE like hypertension, loss of vascular site } \\
\text { access, respiratory and gastrointestinal system-related } \\
\text { issues. Death due to cardiac issues was higher in the } \\
\text { control group. NO anti-EPO antibodies were detected } \\
\text { in either group. SC EPO administration has } \\
\text { demonstrated a better safety profile than IV EPO. }\end{array}$ \\
\hline 3 & $\begin{array}{l}\text { Schaller et al. } \\
\text { / } 1994 \text { [23] }\end{array}$ & $\begin{array}{l}\text { Clinical Trial } \\
\text { (Randomized, } \\
\text { double-blind, } \\
\text { Prospective, } \\
\text { Multi-center } \\
\text { study) }\end{array}$ & $\begin{array}{l}90 \text { adult HD patients already suffering from } \\
\text { ESRD, were enrolled and randomly } \\
\text { assigned to } 4 \text { different groups, } 2 \text { of which } \\
\text { comprised of IV EPO therapy and the other } \\
2 \text { SC EPO therapy. The study involved } 4 \\
\text { different phases of treatment. }\end{array}$ & $\begin{array}{l}30 \% \text { of all treated patients exhibited hypertensive } \\
\text { reactions. During the } \mathrm{Hb} \text { and hematocrit correction } \\
\text { phase, there were more patients becoming } \\
\text { hypertensive with SC EPO therapy than with IV EPO. } \\
\text { This was not the case during the maintenance phase of } \\
\text { treatment, however, SC EPO-treated patients did not } \\
\text { complain about injection site pain and adverse } \\
\text { reactions. The relationship between EPO treatment, } \\
\text { development of hypertension and route of EPO } \\
\text { administration is complex and multifactorial. }\end{array}$ \\
\hline 4 & $\begin{array}{l}\text { Kharagjitsingh } \\
\text { et al. / } 2005 \\
\text { [24] }\end{array}$ & $\begin{array}{l}\text { Multi-center } \\
\text { Cohort study }\end{array}$ & $\begin{array}{l}\text { Existing patient data and serum samples } \\
\text { from } 1677 \text { patients participating in The } \\
\text { Netherlands Cooperative Study on the } \\
\text { Adequacy of Dialysis-2 (NECOSAD-2) were } \\
\text { used in this study. Data was collected at 6- } \\
\text { month intervals between April } 1997 \text { and } \\
\text { September 2002. The study was performed } \\
\text { to detect EPO hyporesponsive patients, } \\
\text { EPO antibodies and PRCA in dialysis } \\
\text { patients. }\end{array}$ & $\begin{array}{l}\text { EPO hyporesponsiveness has numerous causes, } \\
\text { prominently infection, inflammation and depletion of } \\
\text { iron stores. } 57 \text { patients were found to be EPO } \\
\text { hyporesponsive, an estimated incidence of } 16.7 / 1000 \\
\text { patient years on EPO while on dialysis. Only one } \\
\text { patient among the above } 57 \text { patients was found to have } \\
\text { clinical PRCA, an estimated incidence of } 0.29 / 1000 \\
\text { patient years on EPO while on dialysis. The incidence } \\
\text { of EPO antibodies stood at } 1.27 / 1000 \text { patient-years } \\
\text { since the start of dialysis. Out of these } 57 \text { patients } \\
\text { found to be EPO hyporesponsive, } 6 \text { were treated with } \\
\text { EPO IV, while all others used EPO SC. anti-EPO } \\
\text { antibodies and PRCA remain a rare cause of EPO } \\
\text { hyporesponsiveness, though it may be tied to SC EPO } \\
\text { administration. }\end{array}$ \\
\hline 5 & $\begin{array}{l}\text { Navarro et al. } \\
\text { / } 1995 \text { [25] }\end{array}$ & Clinical Trial & $\begin{array}{l}13 \text { chronic haemodialysis patients, who } \\
\text { remained hypertensive after being on long } \\
\text { term (>12 months), thrice weekly, post HD } \\
\text { IV rHuEPO therapy were selected for this } \\
\text { study, with hypertension being defined as } \\
\text { elevated blood pressure that necessitated } \\
\text { the use of anti-hypertensive medications. } \\
\text { These patients were switched to SC EPO } \\
\text { thrice weekly for } 6 \text { months, whilst keeping } \\
\text { the total weekly SC dose at two-third of the }\end{array}$ & $\begin{array}{l}\text { At the end of the first month of the switch to SC } \\
\text { rHuEPO, there was a significant drop in pre-dialysis } \\
\text { mean arterial pressure as opposed to baseline } \\
\text { pressures, prior to the switch. The number of } \\
\text { hypertensive patients reduced from } 13 \text { at the time of } \\
\text { baseline recording to } 8 \text { at the end of the six-month trial. } \\
\text { In the remaining } 8 \text { hypertensive patients, the severity } \\
\text { dropped significantly as was measured by a } \\
\text { "therapeutical score" that assessed hypertensive } \\
\text { severity from the antihypertensive power of the drugs }\end{array}$ \\
\hline
\end{tabular}




\section{Cureus}

weekly IV rHuEPO dose. Their blood pressure was monitored prior to each HD session. Patient's hypertensive therapy and red blood cell indices were also analysed regularly. used to control it. This study shows better control of hypertension with the $\mathrm{SC}$ route of administration in ESRD patients and that SC rHuEPO doesn't prevent hypertension in ESRD patients, rather only reduces its severity compared to the IV route.

\section{TABLE 4: A summary of studies comparing erythropoietin safety profile and tolerance between intravenous and subcutaneous administration}

HD: Haemodialysis, SC: Subcutaneous, IV: Intravenous, Hb: Haemoglobin, rHuEPO: Recombinant Human Erythropoietin, ESRD: End-stage Renal Disease, AE: Adverse events, EPO: Erythropoietin, PRCA: Pure Red Cell Aplasia

Drug-associated Costs

Patients with severe anemia secondary to $\mathrm{CKD}<\mathrm{Hb} 9.0 \mathrm{gm} / \mathrm{dl}$ and those with advanced CKD, for example those on regular HD, need prolonged periods of ESA therapy to improve their QoL, to prevent anemiarelated symptoms, and to minimize the need for blood transfusion [8]. This can incur significant recurring costs on individuals and on healthcare systems. Dealing with this by employing a cost effective yet efficacious means of ESA therapy is therefore crucial (see Table 5).

\begin{tabular}{|c|c|c|c|c|}
\hline $\begin{array}{l}\text { Serial } \\
\text { Number }\end{array}$ & Author/date & Study design & Population & Main points \\
\hline 1 & $\begin{array}{l}\text { Wazny et al. } \\
\text { / } 2013 \text { [26] }\end{array}$ & $\begin{array}{l}\text { Retrospective } \\
\text { Multicenter } \\
\text { Study }\end{array}$ & $\begin{array}{l}\text { Patients were chosen from } 4 \text { in-centre Haemodialysis Units in } \\
\text { Winnipeg, Manitoba, Canada. Patients were treated with Epoetin-alfa } \\
\text { in two separate treatment regimes in two separate time periods - each } \\
\text { lasting } 6 \text { months. } 622 \text { individuals were subject to on IV EPO (period 1), } \\
\text { and } 609 \text { individuals to SC EPO (period 2). Costs were analysed } \\
\text { retrospectively from available patient data and monthly inventory } \\
\text { billing records. }\end{array}$ & $\begin{array}{l}\text { The switch from IV to SC EPO } \\
\text { across } 4 \text { haemodialysis units, } \\
\text { resulted in a } 12.6 \% \text { dose } \\
\text { reduction and saved } 98 \% \text { of } \\
\text { the patients receiving SC } \\
\text { epoetin alpha, about } 1125 \\
\text { USD per person per year. }\end{array}$ \\
\hline 2 & $\begin{array}{l}\text { Galliford et } \\
\text { al. / } 2005 \\
{[17]}\end{array}$ & $\begin{array}{l}\text { Comparative } \\
\text { Study } \\
\text { (prospective } \\
\text { cohort) }\end{array}$ & $\begin{array}{l}86 \text { adult HD patients, already on SC EPO-alfa treatment, were switched } \\
\text { simultaneously to IV EPO-alfa, at the same weekly dose as their SC } \\
\text { administration, for a period of } 6 \text { months. Monthly Red cell indices, } \\
\text { weekly EPO dosages and other parameters were monitored during the } \\
\text { study. }\end{array}$ & $\begin{array}{l}\text { Transitioning from SC to IV } \\
\text { EPO alpha in HD patients } \\
\text { requires a dose increase of } \\
\text { around one-third, possibly } \\
\text { resulting in an annual } \\
\text { increase in cost of } £ 1500 \text { per } \\
\text { patient. }\end{array}$ \\
\hline 3 & $\begin{array}{l}\text { McFarlane } \\
\text { et al. / } 2007 \\
{[27]}\end{array}$ & $\begin{array}{l}\text { Controlled } \\
\text { Clinical Trial }\end{array}$ & $\begin{array}{l}158 \text { adult, chronic, HD patients, already on IV EPO therapy, were } \\
\text { studied for } 1 \text { year prior to the trial. In the study that spanned } 12 \\
\text { months, patients were collectively shifted to SC EPO therapy. }\end{array}$ & $\begin{array}{l}\text { The cost of anemia therapy } \\
\text { rose significantly } 6 \text { months } \\
\text { post-switch to IV EPO } \\
\text { therapy. The median rise in } \\
\text { costs over the whole } 6 \text {-month } \\
\text { period was estimated at } \\
13.1 \% \text { (CAD 665/patient-year; } \\
p<0.01 \text { ). }\end{array}$ \\
\hline 4 & $\begin{array}{l}\text { Prasad et } \\
\text { al. / } 2020 \\
{[28]}\end{array}$ & $\begin{array}{l}\text { Retrospective } \\
\text { Observational } \\
\text { Study }\end{array}$ & $\begin{array}{l}\text { Two hundred and fifteen patients aged more than } 18 \text { years, receiving } \\
\text { in-center HD for at least } 6 \text { months at } 4 \text { HD centers. Patients suffering } \\
\text { from anemia of CKD requiring epoetin alfa therapy, and on IV epoetin } \\
\text { alfa therapy for at least } 6 \text { months, were switched to SC EPO-alfa. Data } \\
\text { was collected from } 6 \text { months prior to } 12 \text { months after the switch. } \\
\text { Primary outcome was the assessment of epoetin-alfa cost per patient } \\
\text { per month before and after the policy change. }\end{array}$ & $\begin{array}{l}\text { Administering epoetin alpha } \\
\text { subcutaneously resulted in a } \\
\text { dose reduction from IV to SC } \\
\text { of } 30.51 \% \text { and } 25 \% \text { reduction } \\
\text { in EPO costs, being equally } \\
\text { effecting at maintaining Hb } \\
\text { levels in patients on HD. }\end{array}$ \\
\hline
\end{tabular}

TABLE 5: A summary of studies comparing healthcare costs between intravenous and subcutaneous EPO administration

HD: Haemodialysis, SC: Subcutaneous, IV: Intravenous, EPO: Erythropoietin, CKD: Chronic Kidney Disease, CAD: Canadian Dollars 


\section{Cureus}

Drug Efficacy

There are various factors that underpin ESA efficacy, i.e., the dose needed to attain a certain target $\mathrm{Hb}$ concentration or hematocrit level, which can be adequately summarized under the umbrella of individual ESA pharmacokinetics and pharmacodynamics [12]. Discussed further are factors that have been found relevant to ESA efficacy (see Table 6). Numerous studies have provided support to the SC route of administration due to multiple advantages over the IV route, most notably a lower overall dose to achieve a similar target $\mathrm{Hb}$ concentration as well as hematocrit levels and a reduced dosing frequency, i.e., the SC route offers more efficacy for administration of r-HuEPO [13-17,19]. Although the SC route offers a much lower level of bioavailability as compared to the IV route, it results in a significantly longer half-life, attaining peak plasma levels that are substantially lower than the IV route but persist for a much longer period of time. The reasons theorized behind this low bioavailability but a paradoxically prolonged maintenance of modest serum plasma levels can be attributed to a multiple injection site, drug inherent and systemic factors. This persistence and delayed absorption of EPO from SC administration has been pivotal in the explanation for this route's effectiveness over the IV route. As erythropoiesis is not as dependent on peak plasma EPO levels as it is on the maintenance of EPO levels above a critical threshold for a prolonged time duration, the SC route offers an advantage. IV EPO dosing results in a fall in serum r-HuEPO levels during the interdialytic period and ultimately in the apoptosis of EPO-dependent erythrocyte precursor cells in the bone marrow. SC EPO dosing prevents this apoptosis due to maintenance of plasma EPO levels for a longer duration therefore enabling a more protracted, efficient and effective process of erythropoiesis $[29,30]$.

\begin{tabular}{|c|c|c|c|c|}
\hline $\begin{array}{l}\text { Serial } \\
\text { Number }\end{array}$ & $\begin{array}{l}\text { Author / } \\
\text { Year }\end{array}$ & Study Type & Population & Relevant Conclusive points \\
\hline 1 & $\begin{array}{l}\text { Brockmöller } \\
\text { et al. / } 1992 \\
\text { [31] }\end{array}$ & $\begin{array}{l}\text { Prospective } \\
\text { study }\end{array}$ & $\begin{array}{l}12 \text { adult, chronic, stable HD patients, } \\
\text { already under treatment with a thrice } \\
\text { weekly IV rcEPO, were subjected to } \\
\text { treatment scheme using regimes of IV and } \\
\text { SC rcEPO recombinant human EPO } \\
\text { (rcEPO) injections in discrete phases to } \\
\text { assess pharmacokinetics and therapeutic } \\
\text { response to both routes. Serum analyses } \\
\text { were carried out at specific time intervals } \\
\text { for achieving the goals of this study. }\end{array}$ & $\begin{array}{l}\text { After first dosing with IV EPO, plasma EPO levels were found } \\
\text { to have a mean ( } \pm \text { S.D.) half-life of } 5.4 \pm 1.70 \text { hours compared } \\
\text { to initial SC EPO administration with a mean( } \pm \text { S.D) } \\
\text { absorption time being } 22 \pm 11 \text { and an average bioavailability } \\
\text { of } 44 \%(28-100 \%) \text {. With continuous long-term treatment with } \\
\text { IV EPO, elimination half-life reduced by } 15 \% \text { to around } 5 \\
\text { hours, possibly a reflection of an increase in hematocrit. The } \\
\text { study suggests that the SC route be more effective due to } \\
\text { prolonged plasma rcEPO elevation following SC } \\
\text { administration, with the exact mechanism being unclear. }\end{array}$ \\
\hline 2 & $\begin{array}{l}\text { Nielsen / } \\
1990 \text { [32] }\end{array}$ & $\begin{array}{l}\text { Clinical } \\
\text { Trial }\end{array}$ & $\begin{array}{l}\text { Two groups of adult, chronic, and stable } \\
\text { HD patients were enrolled. Group } 1 \text { was } \\
\text { already under maintenance treatment with } \\
\text { IV recombinant human EPO (rhEPO) } \\
\text { thrice weekly. Group } 2 \text { included ESRD } \\
\text { patients not previously treated with } \\
\text { rhEPO. Both groups were subjected to IV } \\
\text { and SC rhEPO administration at different } \\
\text { dosages - } 50 \text { U/kg for group } 1 \text { and } 150 \\
\text { U/kg for group } 2 \text {. Pharmacokinetic studies } \\
\text { were then carried out using serum } \\
\text { analytics. }\end{array}$ & $\begin{array}{l}\text { After IV rhEPO injections at the lower dose, the mean half-life } \\
\text { was found to be } 5.4 \pm 0.90 \mathrm{hrs} \text {, while at the higher dose it } \\
\text { was around } 7.60 \mathrm{hrs} \text {. Peak serum EPO levels }\left(\mathrm{C}_{\max }\right) \text { after IV } \\
\text { dosing were found to be } 20 \text { times that of SC } \mathrm{C}_{\max } \text {. Peak } \\
\text { serum EPO levels after SC dosing were reached on an } \\
\text { average of } 27.3 \pm 8.6 \mathrm{hrs} \text {. Mean bioavailability was also found } \\
\text { to be a meager } 14.1 \% \text { after SC dosing. Despite the data, the } \\
\text { protracted maintenance of rhEPO levels after SC } \\
\text { administration may be more efficacious than IV dosing } \\
\text { though more work is needed in this area and patients with } \\
\text { SC administration need to be closely monitored for anti-EPO } \\
\text { antibodies. }\end{array}$ \\
\hline 3 & $\begin{array}{l}\text { Neumayer } \\
\text { et al. / } 1989 \\
\text { [33] }\end{array}$ & $\begin{array}{l}\text { Clinical } \\
\text { Trial }\end{array}$ & $\begin{array}{l}29 \text { adult, chronic, and stable HD patients, } \\
\text { were enrolled and split into } 3 \text { groups. } \\
\text { Group I comprised of } 19 \text { patients who } \\
\text { were treated with IV rhEPO initially, then } \\
\text { kept on maintenance therapy for } 3 \text { months } \\
\text { and thereafter } 10 \text { patients from this group, } \\
\text { making up group II, were subject to } \\
\text { another bolus dose of IV rhEPO at the end } \\
\text { of these } 3 \text { months. Group III was made up } \\
\text { of } 9 \text { additional patients who were treated } \\
\text { with a single SC rhEPO dose. } \\
\text { Pharmacokinetic profiles of these two } \\
\text { administration routes at different stages of } \\
\text { treatment was then assessed using serum } \\
\text { studies. }\end{array}$ & $\begin{array}{l}\text { Peak plasma levels after IV dosing were seen within } 5 \\
\text { minutes of administration and were not significantly different } \\
\text { between Group I and II. IV rhEPO elimination half-life was } \\
\text { found to be an average of } 8.75 \text { ( } 7.29 \text { - } 11.68 \text { ) hours, in Group } \\
\text { I, but fell significantly after } 3 \text { months, i.e. in Group II, to } 6.80 \\
\text { hours. SC rhEPO peak levels, though } 5 \% \text { that of IV levels, } \\
\text { were attained between 18-24 hours after administration, with } \\
\text { a mean half-life of } 11.2 \text { (7.0-13.9) hrs. SC bioavailability was } \\
\text { also low at around } 25 \% \text {. The study questions the benefit of } \\
\text { reaching high peak serum levels immediately after IV } \\
\text { administration and provides support to a relatively low dose } \\
\text { SC administration as mimicking EPO physiological levels in } \\
\text { augmenting erythropoiesis. }\end{array}$ \\
\hline & & & & $\mathrm{C}_{\max }$ for the IP and SC routes are almost identical but only \\
\hline
\end{tabular}




\section{Cureus}

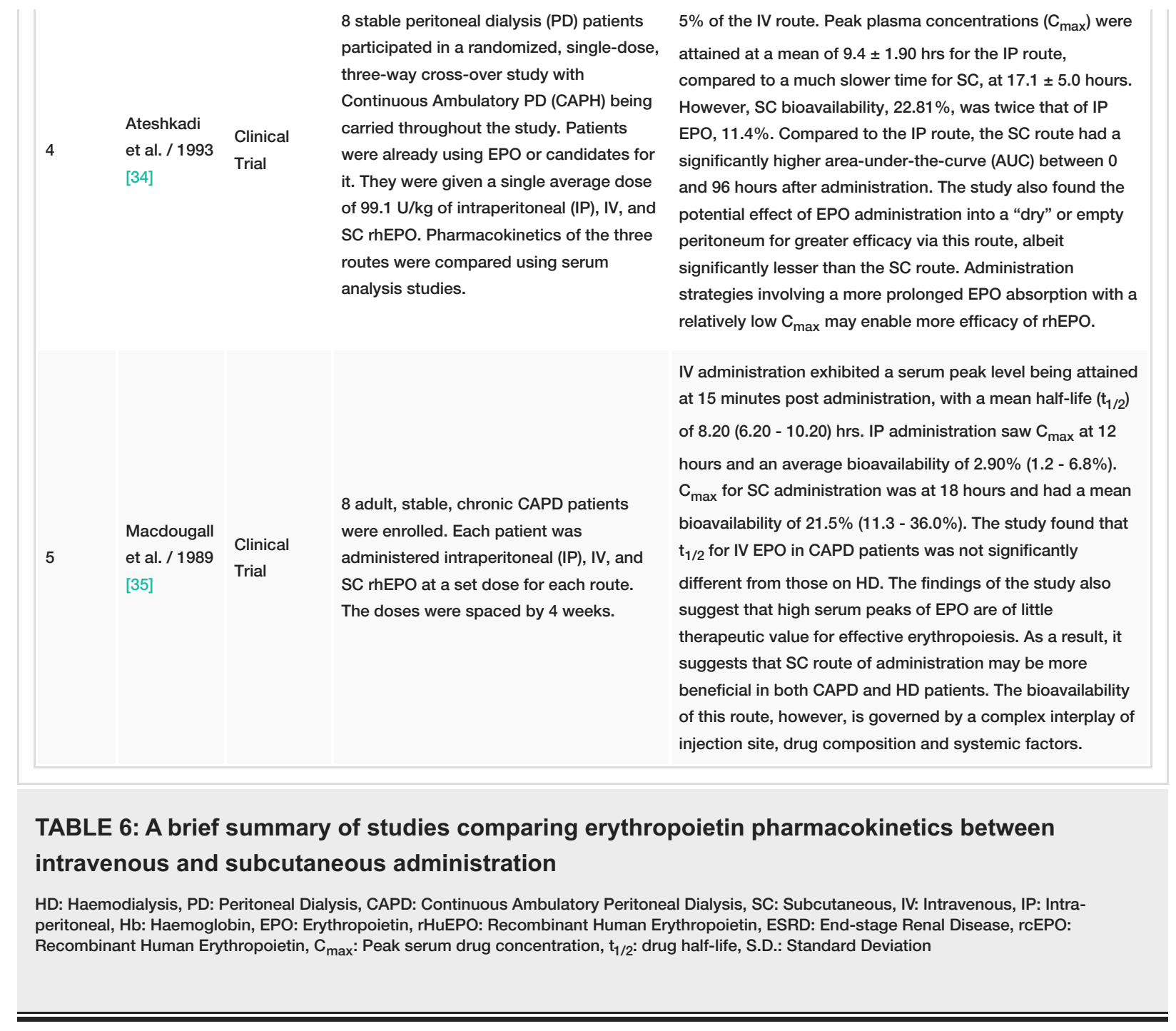

Route of Administration and Stage of CKD (Non-Dialysis Dependent and Patients on Peritoneal Dialysis vs Haemodialysis Patients)

Non-dialysis CKD patients with preserved GFR, or those undergoing peritoneal dialysis, benefit from SC administration of ESAs, considering that it's least invasive and can be carried out without any monitoring. Furthermore, intraperitoneal administration in patients on continuous ambulatory peritoneal dialysis (CAPD), can dilute ESA concentration, limiting its use $[34,35]$. The advantage of IV administration lies in the fact that it can be conveniently administered during the process of haemodialysis. Numerous studies have shown that SC doses of ESAs in non-dialysis dependent and patients on peritoneal dialysis, were found to effectively increase $\mathrm{Hb}$ concentrations and were well-tolerated and may even be more efficacious than IV EPO formulations in HD patients as well [36,37]. However, more work needs to be done comparing the efficacy of SC versus IV EPO administration in non-dialysis and patients on continuous ambulatory peritoneal dialysis (see Table 7). The use of EPO in HD patients has been covered under other sections. 


\section{Cureus}

\begin{tabular}{|c|c|c|c|c|}
\hline $\begin{array}{l}\text { Serial } \\
\text { Number }\end{array}$ & Author/date & Study Design & Population & Main Points \\
\hline 1 & $\begin{array}{l}\text { Hughes et } \\
\text { al. / } 1990 \\
\text { [36] }\end{array}$ & $\begin{array}{l}\text { Randomized } \\
\text { Controlled } \\
\text { Trial }\end{array}$ & $\begin{array}{l}15 \text { adult ESRD patients, on CAPD } \\
\text { for the treatment of ESRD were } \\
\text { enrolled in this study. They were } \\
\text { subjected to treatment with r- } \\
\text { HuEPO thrice weekly SC, with } \\
\text { two separate target } \mathrm{Hb} \text { levels in } \\
\text { two discrete phases - the } \\
\text { correction phase and the } \\
\text { maintenance phase. }\end{array}$ & $\begin{array}{l}\text { Thrice weekly administration of r-HuEPO to subjects on peritoneal } \\
\text { dialysis effectively corrected renal anemia. A reduction in } \\
\text { ineffective erythropoiesis and much more importantly, an increase } \\
\text { in erythroid activity was thought to be the major factor in } \\
\text { increasing red cell volumes. The findings of this study also } \\
\text { suggested that prolonged, moderate increase in serum EPO } \\
\text { concentration is more important than a sudden rise in EPO as } \\
\text { would be observed with IV EPO administration. }\end{array}$ \\
\hline 2 & $\begin{array}{l}\text { Montini et } \\
\text { al. / } 1993 \\
{[37]}\end{array}$ & $\begin{array}{l}\text { Multi-center } \\
\text { Study }\end{array}$ & $\begin{array}{l}24 \text { children, suffering from } \\
\text { anemia secondary to ESRD and } \\
\text { on peritoneal dialysis, aged } 3 \\
\text { months to } 18 \text { years, were treated } \\
\text { with SC r-HuEPO, in varying } \\
\text { doses, depending on the Hb } \\
\text { levels achieved with each dose. }\end{array}$ & $\begin{array}{l}\text { Eighteen patients experienced increased } \mathrm{Hb} \text { levels after } 24 \text { weeks } \\
\text { of treatment from a mean of } 6.5(4.7-7.9) \mathrm{gm} / \mathrm{dl} \text { to } 9.4 \pm 1.7 \mathrm{gm} / \mathrm{dl} \text {. } \\
\text { The IV route of administration is less convenient in patients on } \\
\text { peritoneal dialysis because of lack of vascular access and difficult } \\
\text { self-treatment, while the intraperitoneal route of administration } \\
\text { compromises bioavailability significantly. }\end{array}$ \\
\hline 3 & $\begin{array}{l}\text { Trivedi } \\
\text { and Brooks } \\
\text { / } 2003 \text { [38] }\end{array}$ & $\begin{array}{l}\text { Comparative } \\
\text { Study } \\
\text { (retrospective) }\end{array}$ & $\begin{array}{l}31 \text { pre-dialysis CKD patients' } \\
\text { medical record was assessed. } \\
\text { These patients had been treated } \\
\text { with EPO between } 1996 \text { and } \\
\text { 2001. Various parameters were } \\
\text { assessed including renal } \\
\text { function, red cell indices, and iron } \\
\text { profiles. }\end{array}$ & $\begin{array}{l}\text { The mean hematocrit increased from a baseline value of } 28.4 \pm 2.7 \\
\text { to } 33.6 \pm 3.4 \% \text { after an average of } 6 \text { weeks of treatment and to } 37.7 \\
\pm 4.5 \% \text { after about } 3 \text { months of treatment. By analyzing a variety of } \\
\text { other parameters as well, the study importantly concluded that } \\
\text { pre-dialysis CKD patients exhibited significant response to EPO } \\
\text { therapy without parenteral iron therapy. It was also evident that } \\
\text { pre-dialysis CKD patients had lower overall EPO dosage } \\
\text { requirements than ESRD patients. However, it is important to note } \\
\text { that these findings are similar to the ones in ESRD patients. More } \\
\text { work is specifically needed in pre-dialysis patients for analyzing } \\
\text { dose requirements among the two routes. }\end{array}$ \\
\hline 4 & $\begin{array}{l}\text { Stevens et } \\
\text { al. / } 1991 \\
\text { [39] }\end{array}$ & Clinical Trial & $\begin{array}{l}\text { Sixteen anemic patients with an } \\
\mathrm{Hb}<9 \mathrm{gm} / \mathrm{dl} \text {, maintained on } \\
\text { chronic continuous ambulatory } \\
\text { peritoneal dialysis (CAPD), were } \\
\text { given SC epoetin-alfa thrice } \\
\text { weekly, in two different phases - } \\
\text { each with a higher } \mathrm{Hb} \text { level target } \\
\text { than the previous one. The dose } \\
\text { of SC EPO was changed } \\
\text { periodically, depending upon the } \\
\text { results of red-cell indices and } \\
\text { target Hb levels. }\end{array}$ & $\begin{array}{l}15 \text { patients responded to treatment with a rise in } \mathrm{Hb} \text { concentration } \\
\text { of more than } 2 \mathrm{gm} / \mathrm{dl} \text {. SC administration was found to be } \\
\text { acceptable, convenient more effective in treating anemia in CAPD } \\
\text { patients. It was also associated with an improved QoL and can } \\
\text { very well be thought of as an optimal route of EPO administration } \\
\text { in CAPD patients. Additionally, in the same dialysis unit, it was } \\
\text { found that CAPD patients required a lower dose via the SC route } \\
\text { than HD patients did via the IV route for maintaining target } \mathrm{Hb} \\
\text { levels. }\end{array}$ \\
\hline
\end{tabular}

\section{TABLE 7: A comparison of the different routes of ESA administration with the stage of CKD (Non-}

dialysis dependent AND Patients on Peritoneal Dialysis vs Haemodialysis patients)

HD: Haemodialysis, PD: Peritoneal Dialysis, CAPD: Continuous Ambulatory Peritoneal Dialysis, SC: Subcutaneous, IV: Intravenous, Hb: Haemoglobin, EPO: Erythropoietin, r-HuEPO: Recombinant Human Erythropoietin, ESRD: End-stage Renal Disease, CKD: Chronic Kidney Disease, QoL: Quality of Life

Convenience of Drug Administration

Between the two routes, convenience depends on factors like the stage of CKD, the dose and dosage frequency, the type of ESA being used, ease-of-use, the type of dialysis being utilized, the associated healthcare costs, and patient satisfaction.

For non-HD patients, the SC route may be more generally convenient due to the lack of a continuous IV access, the ease of self administration, comparatively lower dosage, less frequent hospital visits, a reduced dosing frequency and ultimately reduced costs. Even in HD patients, the SC route has been tied to similar advantages and may therefore be more beneficial overall as compared to the IV route, despite the obvious convenience that an arteriovenous fistula confers to IV EPO administration [13-17, 19, 26-28, 31-35]. This 
may be particularly beneficial in low-income countries where affordability and access to newer, longer acting ESAs may be difficult [40]. Evidence lending support to the efficacy, cost effectiveness and safety of the $\mathrm{SC}$ route of ESA administration has been presented in earlier sections.

A multicenter study, non-randomized, open-label study conducted by Grzeszczak et al. in 128 stable, chronic PD patients already on once to thrice-weekly SC EPO administration who were enrolled in a study where the effect of shifting them to once-weekly and once-fortnightly administration of SC Epoetin-beta in maintaining their $\mathrm{Hb}$ concentrations, was investigated. The findings concluded that shifting patients to SC Epoetin-beta once-weekly did not result in a significant change in mean $\mathrm{Hb}$ levels over a period of 25 weeks. In the once-fortnightly group, the dose needed to be increased slightly and even then, more than $50 \%$ of patients could still be maintained on baseline EPO-beta doses or lower. This study paves way for a means of ESA administration that could result in greater convenience, compliance, patient satisfaction, reduced dosage frequency and greater cost savings [41].

The convenience of use for the IV formulation in HD has its possible roots in the preference for its use by HD Staff. This may be due to the routine use of the IV route by HD staff [16] as well as the issue of pain or 'stinging' or discomfort at the injection site associated with the initial use of SC epoetin-alfa which some studies have cited in the past [42]. The KDIGO guidelines have also cited 'pain' secondary to SC

administration, in terms of using short-acting ESAs, as a reason to prefer IV EPO administration, referring to the results of a single centre trial of 30 patients $[8,26]$. In a randomized, un-blinded trial carried out by Kaufman et al. among 208 patients, 86\% of the 107 candidates who received SC epoetin injections reported experiencing pain as none to mild [43]. Similar findings were found in a multi-center randomized, doubleblind, prospective study among 90 ESRD patients already on HD, who were subjected to different regimes of IV and SC EPO treatment. None of the patients treated SC complained of injection site pain nor were there any identifiable local adverse reactions [23]. Nonetheless the pain reported in previous studies has mainly been tied to the citrate component of the epoetin-alfa buffered solution that is administered SC to patients [44]. However, it has largely been controlled by replacement of the citrate preservative with Benzyl Alcohol saline and other newly developed stabilizer solutions, using large gauge needles, and smaller volume doses, all of which were highly effective in reducing pain whilst maintaining drug efficacy $[43,45,46]$.

Type of ESA Formulation Used

ESA can generally be classified as short-acting or long-acting. The former usually refers to the 1st generation ESAs like Epoetin-alfa and beta while the latter normally refers to 2nd generation ESAs and beyond, including formulations like Darbepoetin-alfa and continuous erythropoietin receptor activator (C.E.R.A) [4]. The choice of ESA depends on factors like drug availability, affordability, patient preference, and local policies. Each of these agents also has its own unique pharmacokinetic and pharmacodynamic profiles [4, 8]. In this review we shall only discuss common ESA types from the first and second generations (see Table 8). 


\section{Cureus}

\begin{tabular}{|c|c|c|c|c|}
\hline $\begin{array}{l}\text { Serial } \\
\text { Number }\end{array}$ & $\begin{array}{l}\text { Author / } \\
\text { Year }\end{array}$ & Study Type & Population & Relevant Conclusive Points \\
\hline 1 & $\begin{array}{l}\text { Bernieh } \\
\text { et al. / } \\
2014 \\
{[47]}\end{array}$ & $\begin{array}{l}\text { Randomized } \\
\text { Controlled } \\
\text { Trial }\end{array}$ & $\begin{array}{l}\text { (epoetin-alfa) for the last } 3 \text { months were } \\
\text { randomized to three groups: Group-A-1 } \\
\text { receiving long-acting ESA Darbepoetin-alfa } \\
\text { once weekly, Group-A-2 receiving Darbepoetin- } \\
\text { alfa once in two weeks and Group-B } \\
\text { representing patients continued on Eprex } \\
\text { treatment. }\end{array}$ & $\begin{array}{l}\text { Darbepoetin alfa given weekly or once in two weeks } \\
\text { proved to be more effective (64.8\% of all patients in } \\
\text { Group-A) in achieving target } \mathrm{Hb} \text { levels than epoetin-alfa } \\
(59.7 \% \text { of all patients in Group-B), with significantly less } \\
\text { dose changes and vascular site thrombosis in the former } \\
\text { group compared to the latter. }\end{array}$ \\
\hline 2 & $\begin{array}{l}\text { Sinha et } \\
\text { al. / } \\
2019 \\
{[48]}\end{array}$ & $\begin{array}{l}\text { Clinical Trial } \\
\text { (a } \\
\text { prospective } \\
\text { phase III, } \\
\text { randomized, } \\
\text { open label, } \\
\text { two-arm, } \\
\text { parallel } \\
\text { group, multi- } \\
\text { center study) }\end{array}$ & $\begin{array}{l}\text { Adult anemic, chronic HD dependent patients } \\
\text { already on EPO-alfa, were started on an EPO } \\
\text { regime comprised of Darbepoetin-alfa, in two } \\
\text { phases: correction phase (12-24 weeks) and } \\
\text { maintenance phase (24-36 weeks). } 126 \text { patients } \\
\text { in both phases were randomized in 1:1 ratio to } \\
\text { receive either Darbepoetin-alfa once weekly or } \\
\text { EPO-alfa thrice weekly. }\end{array}$ & $\begin{array}{l}\text { Darbepoetin-alfa, when administered at a reduced } \\
\text { frequency and comparatively lower dose, is similar to } \\
\text { epoetin-alfa in terms of achieving and maintaining target } \\
\mathrm{Hb} \text { levels. Darbepoetin-alfa also has a slightly better } \\
\text { safety profile. This may pave way for achieving methods } \\
\text { of treating renal anemia that are simpler and with mutual } \\
\text { benefits for patients and healthcare staff. }\end{array}$ \\
\hline 3 & $\begin{array}{l}\text { Bommer } \\
\text { et al. / } \\
2008 \\
{[49]}\end{array}$ & $\begin{array}{l}\text { Randomized } \\
\text { Controlled } \\
\text { Trial } \\
\text { (prospective, } \\
\text { randomized, } \\
\text { multicentre } \\
\text { study) }\end{array}$ & $\begin{array}{l}126 \text { adult, chronic, stable HD patients at } 9 \\
\text { German dialysis centres, already on } \\
\text { Darbepoetin-alfa for at least } 6 \text { months, were } \\
\text { randomized to either continue with their } \\
\text { previous treatment plan or to IV Darbepoetin- } \\
\text { alfa in the same dose and frequency. }\end{array}$ & $\begin{array}{l}\text { As opposed to the significant changes in dosage, dose } \\
\text { frequency and incurred costs that one encounters in } \\
\text { changing EPO-alfa from SC to IV administration, } \\
\text { Darbepoetin-alfa does not exhibit such a trend. Instead, it } \\
\text { exhibits a similar pharmacokinetic profile for both the IV } \\
\text { and SC route. Therefore it presents a better cost-benefit } \\
\text { profile and an easier to use choice among ESAs. }\end{array}$ \\
\hline 4 & $\begin{array}{l}\text { Allon et } \\
\text { al. / } \\
2002 \\
{[50]}\end{array}$ & $\begin{array}{l}\text { Clinical Trial } \\
\text { (multicenter, } \\
\text { randomized, } \\
\text { open-label } \\
\text { study) }\end{array}$ & $\begin{array}{l}47 \text { adult, chronic, stable HD patients, already } \\
\text { being treated with IV epoetin since at least } 2 \\
\text { months, were randomized to } 3 \text { treatment } \\
\text { groups for } 6 \text { months - one to receive IV } \\
\text { Darbepoetin alfa once weekly, one to receive IV } \\
\text { Darbepoetin alfa thrice weekly and the last to } \\
\text { receive IV epoetin alfa thrice weekly. }\end{array}$ & $\begin{array}{l}\text { IV Darbepoetin alfa has a } t_{1 / 2} \text { that is } 2-3 \text { times longer } \\
\text { and a clearance } 4 \text { times slower than that of epoetin alfa. } \\
\text { The data gathered showed no changes in Darbepoetin } \\
\text { pharmacokinetics with dose frequency or amount, as } \\
\text { compared to epoetin alfa. The results lend support to the } \\
\text { use of Darbepoetin alfa by healthcare staff owing to its } \\
\text { flexible safety and efficacy at lower and less frequent } \\
\text { doses compared to epoetin. }\end{array}$ \\
\hline
\end{tabular}

TABLE 8: A general comparison of some commonly used 1st and 2nd Generation Erythropoiesis Stimulating Agents, based on previous clinical trails

HD: Haemodialysis, SC: Subcutaneous, IV: Intravenous, Hb: Haemoglobin, EPO: Erythropoietin, rHuEPO: Recombinant Human Erythropoietin, ESRD: End-stage Renal Disease, rcEPO: Recombinant Human Erythropoietin, $\mathrm{t}_{1 / 2}$ : drug half-life, ESA: Erythropoiesis Stimulating Agent

\section{Limitations}

As no review or study is perfect, this literature review has an important set of limitation: papers were excluded if they were published in a language other than English, study types that met our exclusion criteria like commentaries or animal-based studies were excluded, our focus was mainly limited to studies based on adult CKD patients, and we mainly covered 1st and 2nd generation ESAs in our review. Additionally, the majority of studies in anemic CKD patients included in this review pertain to HD dependent ESRD patients. While significant efforts were made to review a broad range of publications from different years, it is still pertinent to mention the selection bias that may be present in this review with regards to the articles chosen for review and their relevance. Future research work that corrects these limitations may very well lead to different outcomes or impressions on the reader.

\section{Conclusions}

The studies discussed in this literature review are suggestive of greater efficacy and benefits via the SC route of EPO administration over the IV route in most cases of chronic kidney disease, keeping in view the factors mentioned earlier - drug costs, efficacy, convenience, dosage frequency, stage of CKD, type of ESA used, and drug safety and tolerability. More work, however, is definitely needed in elucidating the individual effects of 
each of these factors among the two routes of administration, using multi-center randomized trials with much larger sample sizes, especially on the use of ESAs according to the stage of CKD and holistic comparisons of long acting against short acting ESAs, whilst measuring secondary outcomes like patient satisfaction and convenience of use. This may very well help formulate more practical guidelines, help improve the efficiency of ESA use, ensure cost saving, improve quality of care for patients and provide clinicians with better insight during decision making.

\section{Additional Information \\ Disclosures}

Conflicts of interest: In compliance with the ICMJE uniform disclosure form, all authors declare the following: Payment/services info: All authors have declared that no financial support was received from any organization for the submitted work. Financial relationships: All authors have declared that they have no financial relationships at present or within the previous three years with any organizations that might have an interest in the submitted work. Other relationships: All authors have declared that there are no other relationships or activities that could appear to have influenced the submitted work.

\section{References}

1. Stauffer ME, Fan T: Prevalence of anemia in chronic kidney disease in the United States . PloS ONE. 2014, 9:e84943. 10.1371/journal.pone.0084943

2. Smith RE Jr: The clinical and economic burden of anemia . Am J Manag Care. 2010, 16:59-66.

3. Mehdi U, Toto RD: Anemia, diabetes, and chronic kidney disease . Diabetes Care. 2009, 32:1320-1326. 10.2337/dc08-0779

4. Hayat A, Haria D, Salifu MO: Erythropoietin stimulating agents in the management of anemia of chronic kidney disease. Patient Prefer Adherence. 2008, 2:195-200. 10.2147/ppa.s2356

5. Tanhehco YC, Berns IS: Red blood cell transfusion risks in patients with end-stage renal disease . Semin Dial. 2012, 25:539-544. 10.1111/j.1525-139X.2012.01089.x

6. Biggar P, Kim GH: Treatment of renal anemia: erythropoiesis stimulating agents and beyond . Kidney Res Clin Pract. 2017, 36:209-223. 10.23876/j.krcp.2017.36.3.209

7. Thamer M, Zhang Y, Kaufman J, Cotter D, Dong F, Hernán MA: Dialysis facility ownership and epoetin dosing in patients receiving hemodialysis. JAMA. 2007, 297:1667-1674. 10.1001/jama.297.15.1667

8. Kidney Disease: Improving Global Outcomes (KDIGO) Anemia Work Group. KDIGO clinical practice guideline for anemia in chronic kidney disease. Kidney Inter Suppl. 2012, 2:279-335.

9. Bennett CL, Spiegel DM, Macdougall IC, et al.: A review of safety, efficacy, and utilization of erythropoietin, darbepoetin, and peginesatide for patients with cancer or chronic kidney disease: a report from the Southern Network on Adverse Reactions (SONAR). Semin Thromb Hemost. 2012, 38:783-796. 10.1055/s0032-1328884

10. Patel TV, Robinson K, Singh AK: Is it time to reconsider subcutaneous administration of epoetin? . Nephrol News Issues. 2007, 21:57.

11. Pollock C, Johnson DW, Hörl WH, et al.: Pure red cell aplasia induced by erythropoiesis-stimulating agents . Clin J Am Soc Nephrol. 2008, 3:193-199. 10.2215/CJN.02440607

12. Besarab A: Optimizing anaemia management with subcutaneous administration of epoetin. Nephrol Dial Transplant. 2005, 20:10-15. 10.1093/ndt/gfh1098

13. Muirhead N, Churchill DN, Goldstein M, et al.: Comparison of subcutaneous and intravenous recombinant human erythropoietin for anemia in hemodialysis patients with significant comorbid disease. Am J Nephrol. 1992, 12:303-310. 10.1159/000168464

14. Wright DG, Wright EC, Narva AS, Noguchi CT, Eggers PW: Association of erythropoietin dose and route of administration with clinical outcomes for patients on hemodialysis in the United States. Clin J Am Soc Nephrol. 2015, 10:1822-1830. 10.2215/CJN.01590215

15. Vercaigne LM, Collins DM, Penner SB: Conversion from subcutaneous to intravenous erythropoietin in a hemodialysis population. J Clin Pharmacol. 2005, 45:895-900. 10.1177/0091270005278808

16. Moist LM, Muirhead N, Wazny LD, Gallo KL, Heidenheim AP, House AA: Erythropoietin dose requirements when converting from subcutaneous to intravenous administration among patients on hemodialysis. Ann Pharmacother. 2006, 40:198-204. 10.1345/aph.1G425

17. Galliford JW, Malasana R, Farrington K: Switching from subcutaneous to intravenous erythropoietin alpha in haemodialysis patients requires a major dose increase. Nephrol Dial Transplant. 2005, 20:1956-1962. 10.1093/ndt/gfh899

18. Steffensen GK, Stergaard O: Administration of the same dose of epoetin-beta intravenously and subcutaneously to patients with renal anaemia. Scand J Urol Nephrol. 2011, 45:461-469. 10.3109/00365599.2011.592856

19. Parker KP, Mitch WE, Stivelman JC, Macon EJ, Bailey JL, Sands JM: Safety and efficacy of low-dose subcutaneous erythropoietin in hemodialysis patients. J Am Soc Nephrol. 1997, 8:288-293.

20. Singbartl G: Adverse events of erythropoietin in long-term and in acute/short-term treatment . Clin Investig. 1994, 72:36-43.

21. Lee YK, Koo JR, Kim JK, et al.: Effect of route of EPO administration on hemodialysis arteriovenous vascular access failure: a randomized controlled trial. Am J Kidney Dis. 2009, 53:815-822. 10.1053/j.ajkd.2008.12.035

22. Klinkmann H, Schmidt R, Wieczorek L, Scigalla P: Adverse events of subcutaneous recombinant human erythropoietin therapy. Contrib Nephrol. 1992, 100:127-138. 10.1159/000421456

23. Schaller R, Sperschneider H, Thieler H, et al.: Differences in intravenous and subcutaneous application of recombinant human erythropoietin: a multicenter trial. Artif Organs. 1994, 18:552-558. 10.1111/j.15251594.1994.tb03378.x 
24. Kharagjitsingh AV, Korevaar JC, Vandenbroucke JP, Boeschoten EW, Krediet RT, Daha MR, Dekker FW: Incidence of recombinant erythropoietin (EPO) hyporesponse, EPO-associated antibodies, and pure red cell aplasia in dialysis patients. Kidney Int. 2005, 68:1215-1222. 10.1111/j.1523-1755.2005.00514.x

25. Navarro JF, Teruel JL, Marcén R, Ortuño J: Improvement of erythropoietin-induced hypertension in hemodialysis patients changing the administration route. Scand J Urol Nephrol. 1995, 29:11-14. 10.3109/00365599509180532

26. Wazny LD, Raymond CB, Sood AR, Eng A, Verrelli M: Cost analysis of an intravenous to subcutaneous epoetin $\alpha$ conversion. Am J Nephrol. 2013, 38:496-500. 10.1159/000357052

27. McFarlane PA, Hillmer MP, Dacouris N: A change from subcutaneous to intravenous erythropoietin increases the cost of anemia therapy. Nephron Clin Pract. 2007, 107:90-96. 10.1159/000108649

28. Prasad B, Jafari M, Toppings J, Gross L, Kappel J, Au F: Economic benefits of switching from intravenous to subcutaneous epoetin alfa for the management of anemia in hemodialysis patients. Can J Kidney Health Dis. 2020, 7:2054358120927532. 10.1177/2054358120927532

29. Elliott S, Pham E, Macdougall IC: Erythropoietins: a common mechanism of action . Exp Hematol. 2008, 36:1573-1584. 10.1016/j.exphem.2008.08.003

30. Besarab A: Physiological and pharmacodynamic considerations for route of EPO administration . SeminNephrol. 2000, 20:364-374.

31. Brockmöller J, Köchling J, Weber W, Looby M, Roots I, Neumayer HH: The pharmacokinetics and pharmacodynamics of recombinant human erythropoietin in haemodialysis patients. Br J Clin Pharmacol. 1992, 34:499-508.

32. Nielsen OJ: Pharmacokinetics of recombinant human erythropoietin in chronic haemodialysis patients . Pharmacol Toxicol. 1990, 66:83-86. 10.1111/j.1600-0773.1990.tb00710.x

33. Neumayer HH, Brockmöller J, Fritschka E, Roots I, Scigalla P, Wattenberg M: Pharmacokinetics of recombinant human erythropoietin after SC administration and in long-term IV treatment in patients on maintenance hemodialysis. Contrib Nephrol. 1989, 76:131-142. 10.1159/000417889

34. Ateshkadi A, Johnson CA, Oxton LL, Hammond TG, Bohenek WS, Zimmerman SW: Pharmacokinetics of intraperitoneal, intravenous, and subcutaneous recombinant human erythropoietin in patients on continuous ambulatory peritoneal dialysis. Am J Kidney Dis. 1993, 21:635-642. 10.1016/s02726386(12)80037-0

35. Macdougall IC, Roberts DE, Neubert P, Dharmasena AD, Coles GA, Williams JD: Pharmacokinetics of intravenous, intraperitoneal, and subcutaneous recombinant erythropoietin in patients on CAPD. A rationale for treatment. Contrib Nephrol. 1990, 76:112-121. 10.1159/000417887

36. Hughes RT, Cotes PM, Pippard MJ, Stevens JM, Oliver DO, Winearls CG, Royston JP: Subcutaneous administration of recombinant human erythropoietin to subjects on continuous ambulatory peritoneal dialysis: an erythrokinetic assessment. Br J Haematol. 1990, 75:268-273. 10.1111/j.13652141.1990.tb02661.x

37. Montini G, Zacchello G, Perfumo F, et al.: Pharmacokinetics and hematologic response to subcutaneous administration of recombinant human erythropoietin in children undergoing long-term peritoneal dialysis: a multicenter study. J Pediatr. 1993, 122:297-302. 10.1016/s0022-3476(06)80137-x

38. Trivedi HS, Brooks BJ: Erythropoietin therapy in pre-dialysis patients with chronic renal failure: lack of need for parenteral iron. Am J Nephrol. 2003, 23:78-85. 10.1159/000068033

39. Stevens JM, Auer J, Strong CA, Hughes RT, Oliver DO, Winearls CG, Cotes PM: Stepwise correction of anaemia by subcutaneous administration of human recombinant erythropoietin in patients with chronic renal failure maintained by continuous ambulatory peritoneal dialysis. Nephrol Dial Transplant. 1991, 6:487-494. 10.1093/ndt/6.7.487

40. Hahn D, Esezobor CI, Elserafy N, Webster AC, Hodson EM: Short-acting erythropoiesis-stimulating agents for anaemia in predialysis patients. Cochrane Database Syst Rev. 2017, 1:011690. 10.1002/14651858.CD011690.pub2

41. Grzeszczak W, Sulowicz W, Rutkowski B, et al.: The efficacy and safety of once-weekly and once-fortnightly subcutaneous epoetin beta in peritoneal dialysis patients with chronic renal anaemia. Nephrol Dial Transplant. 2005, 20:936-944. 10.1093/ndt/gfh761

42. Ashai NI, Paganini EP, Wilson JM: Intravenous versus subcutaneous dosing of epoetin: a review of the literature. Am J Kidney Dis. 1993, 22:23-31. 10.1016/0272-6386(93)70178-2

43. Kaufman JS, Reda DJ, Fye CL, et al.: Subcutaneous compared with intravenous epoetin in patients receiving hemodialysis. N Engl J Med. 1998, 339:578-583. 10.1056/NEJM199808273390902

44. Frenken LA, van Lier HJ, Jordans JG, Leunissen KML, van Leusen R, Verstappen VMC, Koene RAP: Identification of the component part in an epoetin alfa preparation that causes pain after subcutaneous injection. Am J Kidney Dis. 1993, 22:553-556. 10.1016/s0272-6386(12)80928-0

45. Cheung WK, Natarajan J, Sanders M, Vercammen E: Comparative pharmacokinetics, safety, and tolerability after subcutaneous administration of recombinant human erythropoietin formulated with different stabilizers. Biopharm Drug Dispos. 2000, 21:211-219. 10.1002/bdd.231

46. Frenken LA, van Lier HJ, Koene RA: Analysis of the efficacy of measures to reduce pain after subcutaneous administration of epoetin alfa. Nephrol Dial Transplant. 1994, 9:1295-1298.

47. Bernieh B, Abouchacra S, Boobes Y, et al.: Comparison between short- and long-acting erythropoiesisstimulating agents in hemodialysis patients: target hemoglobin, variability, and outcome. Int Urol Nephrol. 2014, 46:453-459. 10.1007/s11255-013-0640-7

48. Sinha SD, Bandi VK, Bheemareddy BR, et al.: Efficacy, tolerability and safety of darbepoetin alfa injection for the treatment of anemia associated with chronic kidney disease (CKD) undergoing dialysis: a randomized, phase-III trial. BMC Nephrol. 2019, 20:90. 10.1186/s12882-019-1209-1

49. Bommer J, Asmus G, Wenning M, Bommer G: A comparison of haemoglobin levels and doses in haemodialysis patients treated with subcutaneous or intravenous darbepoetin alfa: a German prospective, randomized, multicentre study. Nephrol Dial Transplant. 2008, 23:4002-4008. 10.1093/ndt/gfn416

50. Allon M, Kleinman K, Walczyk M, et al.: Pharmacokinetics and pharmacodynamics of darbepoetin alfa and epoetin in patients undergoing dialysis. Clin Pharmacol Ther. 2002, 72:546-555. 10.1067/mcp.2002.128374 